Verena Meier

\section{DIE GEDENKSTÄTTE FÜR SOWJETISCHE KRIEGSGEFANGENE IN GUDENDORF - ERINNERUNG IM KALTEN KRIEG}

Das Schicksal der sowjetischen Kriegsgefangenen, der zweitgrößten Opfergruppe nationalsozialistischer Gewaltverbrechen, spielt in der bundesdeutschen Erinnerung nur eine marginale Rolle. Bundespräsident Joachim Gauck äußerte 2015, dass ihre Geschichte in einem „Erinnerungsschatten“ liege. Das Regionalbeispiel Gudendorf zeigt indes, dass dies nicht überall der Fall war, die Erinnerung an sowjetische Kriegsgefangene mitunter gar aktiv geschichtspolitisch genutzt wurde.

In Anlehnung an das Analyseraster der „Geschichtspolitik“werden die durch Erinnerungspraktiken vermittelten „Geschichtsbilder“ unterschiedlicher Akteure untersucht, die ab 1945 in drei Phasen Geschichtsdeutungen für politische Zwecke nutzten: In der ersten Phase bis 1949 errichteten die britische Militärregierung und die sowjetische Militärkommission ein Ehrenmal für die verstorbenen sowjetischen Kriegsgefangenen. Die zweite Phase von 1949 bis 1983, in der Gudendorf seine zentrale Rolle erhielt, war vom erinnerungspolitischen Engagement der Bundesregierung, der schleswig-holsteinischen Landesregierung und des Volksbunds Deutsche Kriegsgräberfürsorge geprägt. In einer dritten Phase ab 1983 nutzte die Graswurzelinitiative „Blumen für Gudendorf“ die Gedenkstätte als Plattform, um an das Schicksal sowjetischer Kriegsgefangener in deutschem Gewahrsam zu erinnern und gleichzeitig vor einem erneuten Krieg zu warnen. Da die meisten Mitglieder dieser Initiative auch in der Friedensbewegung aktiv waren, verbanden sich Bemühungen um die historische Aufarbeitung und erinnerungskulturelle Praktiken im Kontext des Kalten Krieges mit politischer Agitation. Die Auseinandersetzungen um die ersten beiden Denkmäler, ihre Gestaltung und die durch sie vermittelten „Geschichtsbilder", die vor dem Hintergrund der Berlin-Blockade und der Errichtung der Berliner Mauer ausgetragen wurden, machen dies ebenso deutlich wie die Friedensbewegung und die Initiative „Blumen für Gudendorf“, die im Kontext des NATO-Doppelbeschlusses von 1979 zu sehen sind.

Gefragt wird ferner, inwieweit Geschichtsbilder über verschiedene Akteursgruppen und Phasen hinaus transferiert wurden, welche Motivationen jeweils hinter den verschiedenen Erinnerungspraktiken standen und in welchem Kontext sie zu verstehen sind. In den ersten beiden Phasen wurde vor allem über die Verwendung nationaler Symboliken, die Bezeichnung der Opfer und der Umstände ihres Todes in deutscher Kriegsgefangenschaft gestritten: Während die sowjetische
Gräberkommission betonen wollte, dass Sowjetmenschen „in faschistischer Gefangenschaft" gestorben seien, forderten mehrere Kreise in Schleswig-Holstein und Niedersachsen, es müsse „in deutscher Gefangenschaft“ heißen. Schließlich sprach die Inschrift verschleiernd von „sowjetischen Bürgern“, stand aber im Einklang mit dem nationalen Narrativ der Sowjetunion, in dem die Partisanen und Rotarmisten als Befreier Europas vom „Faschismus“ geehrt wurden, während Kriegsgefangene als potenzielle „Vaterlandsverräter" galten. Das zweite Denkmal bot keinen Hinweis auf die Todesumstände der Gefangenen und entsprach dem Verlangen der frühen Bundesrepublik, deutsche Schuld zu beschweigen bzw. einen „Schlussstrich“ zu ziehen.

Mit dem Ausbau zur zentralen Gedenkstätte für sowjetische Kriegsgefangene in Schleswig-Holstein und den Umbettungen sowjetischer Kriegsgefangener aus dem ganzen Bundesland um 1958 gelangte das Landesinnenministerium zu der Erkenntnis, dass in Gudendorf während des Krieges rund 3000 sowjetische Kriegsgefangene verstorben seien und die Zahl der Opfer eine erheblich gröBere Dimension hatte als die 40 bis 350 Toten, von denen man in den frühen Nachkriegsjahren ausgegangen war. Die höhere Zahl propagierten vor allem die Akteure der dritten Phase, die sich für eine Aufarbeitung der NS-Verbrechen an den sowjetischen Kriegsgefangenen einsetzten. Das dabei geprägte Bild vom „Sterbelager" in Gudendorf ist bis heute wirksam, obwohl neue Forschungen dies inzwischen differenzieren und widerlegen konnten.

Schlagwörter: Sowjetische Kriegsgefangene, Denkmäler, sowjetische Gräberkommission, Kalter Krieg, Geschichtspolitik.

Die Gedenkstätte Gudendorf im Kreis Süderdithmarschen ist die größte Gedenkstätte in Schleswig-Holstein, die an die während des Zweiten Weltkriegs in deutscher Gefangenschaft verstorbenen sowjetischen Kriegsgefangenen erinnert. Von 5,7 Millionen Rotarmisten überlebten bis zu 3,3 Millionen die deutsche Kriegsgefangenschaft nicht ${ }^{1}$. Ein breites Netz von Stammlagern (Stalag), Arbeitslagern und lokalen Arbeitskommandos entstand seit Kriegsbeginn im gesamten Deutschen Reich. Auch

${ }^{1}$ Vgl. Rolf Keller, Sowjetische Kriegsgefangene im Deutschen Reich 1941/42. Behandlung und Arbeitseinsatz zwischen Vernichtungspolitik und kriegswirtschaftlichen Zwängen (Göttingen Wallstein, 2011),20f. Es gibt bisher noch keine eindeutige Gesamtzahl der gefangengenommenen Rotarmisten sowie der Todesfälle. Abweichend nennt Streim 5,3 Millionen sowjetische Gefangene, wovon mindestens 253 Millionen gestorben seien. Vgl. Alfred Streim, Die Behandlung sowjetischer Kriegsgefangener im Fall Barbarossa" (Heidelberg/Karlsruhe: C.F. Miler, Forschungen mit einer verbesserten Quellenlage durch die Nutzung der seit fast zwanzig Jahren zugänglichen Gefangenenkarteiunterlagen liefern verlässliche Zahlen für Teilbereiche des deutschen Herrschaftsgebietes, vgl. Reinhard Otto, Rolf Keller, und Jens Nagel, „Sowjetische Kriegsgefangene in deutschem Gewahrsam 1941-1945. Zahlen und Dimensionen“, Vierteljahreshefte für Zeitgeschich te 4 (2008): 557-602. 
in Schleswig-Holstein gab es zahlreiche Lager und Arbeitskommandos, darunter in Gudendorf. Doch lange lag das Leid der sowjetischen Kriegsgefangenen in der gesamtdeutschen Erinnerung in einem „Erinnerungsschatten“ wie der damalige Bundespräsident Joachim Gauck anlässlich des 70. Jahrestages des Kriegsendes in Stukenbrock auf dem Friedhof des früheren Stalags 326 (VI K) Senne betonte:

Und für uns bleibt festzuhalten, dass der millionenfache Tod derer, die unter der Verantwortung der Deutschen Wehrmacht starben, „eines der größten deutschen Verbrechen des Zweiten Weltkriegs“" gewesen ist. [...]

Aus mancherlei Gründen ist dieses grauenhafte Schicksal der sowjetischen Kriegsgefangenen in Deutschland nie angemessen ins Bewusstsein gekommen - es liegt bis heute in einem Erinnerungsschatten².

Im Gegensatz zum allgemeinen Erinnerungsdiskurs auf nationaler Ebene war das Leid der sowjetischen Kriegsgefangenen in Gudendorf nicht im „Erinnerungsschatten“. Schon früh gab es hier verschiedene Initiativen für ein angemessenes Gedenken.

\section{Untersuchungsgegenstand und Methode}

Bereits kurz nach dem Ende des Zweiten Weltkriegs wurde in Gudendorf ein erstes Ehrenmal zur Erinnerung an die verstorbenen sowjetischen Kriegsgefangenen durch die sowjetische Militärkommission in Lübeck in Absprache mit der britischen Militärregierung errichtet. Mit dem „Besatzungsstatut zur Abgrenzung der Befugnisse und Verantwortlichkeiten zwischen der zukünftigen deutschen Regierung und der Alliierten Kontrollbehörde" von 1949 wurden der deutschen Regierung neben anderen Aufgaben auch jene rund um die Fürsorge von Kriegsgräbern übertragen. In den 1950er Jahren wählte das Land Schleswig-Holstein Gudendorf als zentralen Begräbnisplatz für Umbettungen von verstorbenen sowjetischen Kriegsgefangenen aus und beschloss den Ausbau des Begräbnisplatzes zur zentralen Gedenkstätte mit einem neuen Denkmal, welches 1961 fertiggestellt wurde. Neben diesen Top-Down-Initiativen zur Errichtung von Denkmälern nutzten Graswurzelbewegungen, darunter ab 1983 die Initiative „Blumen für Gudendorf“, die Gedenkstätte nicht nur, um an das Schicksal der

2 Joachim Gauck, „Rede zum 70. Jahrestag des Endes des Zweiten Weltkrieges am 6. Mai 2015 in Schloss Holte-Stukenbrock", accessed January 19, 2019, http://www.bundespraesident.de/ Sharedocs SharedDocs/Reden/DE/Joachim-Gauck/Reden/2015/05/150506-Holte-Stukenbrock.html. Für eine wissenschaftlichen Beitrag über den Stellenwert dieser Gruppe in der deutschen Erinnerungskultur sei auf folgenden Artikel verwiesen: Peter Jahn, „Das Schicksal sowjetischer Kriegsgefangener in der deutschen Erinnerung", in „Ich werde es nie vergessen“. Briefe sowjetischer Kriegsgefangener 20042006 (Berlin: Ch. Links, 2007), 30-35. sowjetischen Kriegsgefangenen zu erinnern, sondern auch um vor einem neuen Krieg zu warnen und sich für Frieden und Abrüstung einzusetzen.

In der Regel sind soziale oder politische Konflikte Anlässe zur Entstehung von Denkmälern ${ }^{3}$. In Bezug auf den Inhalt von Denkmälern hebt Dietrich Erben hervor, dass diese vor allem Geschichtsbilder der Zeit transportieren, in der sie errichtet wurden, und dass diese Bilder je nach gegebenem zeitlichen Kontext variieren ${ }^{4}$. In diesem Artikel werden die Aneignung von Geschichte und die transportierten „Geschichtsbilder“ im jeweiligen Entstehungskontext beider Denkmäler in Gudendorf sowie im Umgang mit ihnen nach ihrer Fertigstellung analysiert.

Da beide in Gudendorf errichteten Denkmäler aus einer Top-Down Initiative, also von Regierungsinstitutionen statt von zivilgesellschaftlichen Bemühungen (Bottom-up) errichtet wurden, und die Initiative „Blumen für Gudendorf" ihre erinnerungskulturellen Praktiken mit bestimmten politischen Zielsetzungen verband, wird im Folgenden auf das Konzept der „Geschichtspolitik“ als Analyseinstrument zurückgegriffen. Edgar Wolfrum definiert Geschichtspolitik als ,ein Handlungs- und Politikfeld, auf dem verschiedene Akteure Geschichte mit ihren spezifischen Interessen befrachten und politisch zu nutzen suchen" ${ }^{5}$. Harald Schmid lieferte daran anschließend folgende Definition: „Geschichtspolitik sollen jene Diskurse und Handlungen heißen, mit denen die Deutung von Geschichte als gegenwärtige öffentliche Repräsentation einer kollektiv relevanten Vergangenheit zu politischen Zwecken betrieben wird" 6 . Um Erinnerung an vergangene Ereignisse im öffentlichen Raum zu gestalten und kollektive Identitäten zu konstruieren, bedienen sich die Akteure unterschiedlicher Strategien, wozu unter anderem die Errichtung von Denkmälern und darauf bezogene erinnerungskulturelle Praktiken gezählt werden können.

Als Analyseraster dient im Folgenden Wolfrums Unterscheidung zwischen Akteuren, Kontexten, Phasen und Medien ${ }^{7}$. Da die hier untersuch-

${ }_{3}^{3}$ Dietrich Erben, „Denkmäler“, in Handbuch der politischen Ikonographie, hrsg. von Uwe Fleckner, Martin Warnke und Hendrik Ziegler, Band I (München: Beck, 2011), 235.

${ }^{4}$ Erben, „Denkmäler“, 235.

${ }^{5}$ Edgar Wolfrum, Geschichtspolitik in der Bundesrepublik Deutschland. Der Weg zur bundesrepublikanischen Erinnerung 1948-1990 (Darmstadt: Wissenschaftliche Buchgesellschaft, 1999), 25. Siehe auch: Stefan Troebst, „Geschichtspolitik“, Docupedia, accessed August 23, 2018, http://docupedia.de/ images/1/13/Geschichtspolitik.pdf.

${ }^{6}$ Harald Schmid, „Konstruktion, Bedeutung, Macht. Zum kulturwissenschaftlichen Profil einer Analyse von Geschichtspolitik“, in Geschichtspolitik und sozialwissenschaftliche Theorie, hrsg. von Horst-Alfred Heinrich und Michael Kohlstruck (Stuttgart: Steiner, 2008), 78; siehe auch: Troebst, "Geschichtspolitik“.

7 Edgar Wolfrum, „Erinnerungskultur und Geschichtspolitik als Forschungsfelder", in Reformation und Bauernkrieg. Erinnerungskultur und Geschichtspolitik im geteilten Deutschland, hrsg. von Jan Scheunemann (Leipzig: Evangelische Verlagsanstalt, 2010), 21-24. 
ten Denkmäler an einem Ort errichtet wurden, den die Wehrmacht zur Zeit des Krieges bereits als Begräbnisplatz für die in Gudendorf verstorbenen sowjetischen Kriegsgefangenen nutzte, wird zunächst ein Abriss über die Geschichte des Lagers gegeben ${ }^{8}$.

\section{Das sowjetische Kriegsgefangenenlager und erweiterte Krankenrevier in Gudendorf}

Die Entstehung des Lagerkomplexes in Gudendorf geht zurück auf die Luftwaffe, die bereits vor dem Beginn des Zweiten Weltkriegs ihr Netz an Flugplätzen und Einsatzhäfen entlang der Nordseeküste ausbaute. Mit der Ausweitung des Arbeitseinsatzes von sowjetischen Kriegsgefangenen zum „Großeinsatz“ im Oktober 1941 sollte in Gudendorf ein Arbeitskommando der Luftwaffe aufgestellt und die Gefangenen zu Forstarbeiten und Abholzungen herangezogen werden. Zeitzeugen erinnern sich, dass die Gefangenen für das zivile Holzhandelsunternehmen Gehlsen aus Heide Abholzarbeiten verrichten mussten, um den Flugplatz anzulegen ${ }^{9}$. Sie ersetzten spätestens ab Frühjahr 1943 zuvor dort eingesetzte französische Kriegsgefangene $^{10}$. Im März 1944 verlegte die Wehrmacht das sowjetische Kriegsgefangenenlager in Heidkaten mit erweitertem Krankenrevier, das bis dahin als Zweiglager des Stammlager X A galt, nach Gudendorf. Damit war das Gefangenenlager mit erweiterten Krankrevier in Gudendorf für die medizinische Versorgung von sowjetischen Kriegsgefangenen aus dem gesamten Bereich des Stammlagers X A zuständig, d.h. für die Regionen Hamburg und Schleswig-Holstein ${ }^{11}$.

Für den Zeitraum von Juni 1941 bis Mai 1945 konnten insgesamt 36 in Gudendorf verstorbene Kriegsgefangene namentlich ermittelt werden ${ }^{12}$.

\footnotetext{
${ }^{8}$ Die Darstellungen in diesem Aufsatz beruhen auf Ergebnissen meiner Untersuchung zur Geschichte und Erinnerungsgeschichte des Lagers und der Gedenkstätte für sowjetische Kriegsgefangene, die 2020 veröffentlicht werden: Verena Meier, „Das Lager und die Gedenkstätte für sowjetische Kriegsgefangene in Gudendorf - Geschichte und Erinnerungskultur", in Schriftenreihe der Bürgerstiftung SchleswigHolsteinische Gedenkstätten, Band I (derzeit in Fertigstellung).

${ }_{9}^{9}$ Zeitzeugengespräch mit Hans Jakob Beeck (geb. am 06.05.1930) vom 11.09.2017.

${ }^{10}$ Anordnungen zur Erleichterung für französische Kriegsgefangene in reinen Franzosenlagern des Hauptwachmanns und Kompanie-Chefs der 6. Kompanie des Landesschützenbataillons 682 Meldorf Sebastiani vom 22.10.1941, Anlage zum Schreiben der 6. Kompanie des Landesschützenbataillons 682 aus Meldorf an den Kreisbauernführer von Süderdithmarschen vom 23.10.1941 über die Auflockerung aus Meldorf an den Kreisbauernführer von Süderdithmarschen vom 23.10.1941 über die Auflockerung
der Bewachung der französischen Kriegsgefangenen, Akte Kreisbauernschaft Süder-Dithmarschen 1937-1943 [1944], Nachlass von Hans Beeck in der privaten Sammlung von Hans Jakob Beeck.

11 Brief von Gustav Toosbuy an Gerhard Hoch vom 26.02.1978, Sammlung der KZ-Gedenkstätte Kaltenkirchen, Nachlass von Gerhard Hoch, bisher ohne Signatur.

${ }^{12}$ Martin Gietzelt konnte lediglich 20 im erweiterten Krankenrevier in Gudendorf verstorbene Kriegsgefangene nachweisen, vgl. Martin Gietzelt, „Die Gedenkstätte Gudendorf. Neue
}

Sie starben allesamt zwischen Mai 1944 und Anfang Mai 1945 im erweiterten Krankenrevier oder im Gefangenenlager. Besonders der Winter 1941/42 war gekennzeichnet durch ein Massensterben sowjetischer Kriegsgefangener im gesamten Deutschen Reich. Die Wehrmacht ignorierte ihre Grundbedürfnisse weitgehend. Bemühungen, konkrete biografische Nachweise für sowjetische Kriegsgefangene zu finden, die bereits zur Zeit des Kriegsgefangenenlagers der Luftwaffe zwischen November 1941 und Frühjahr 1944 in Gudendorf verstarben und beerdigt wurden, blieben erfolglos. Administrative Quellen der britischen Militärregierung, der sowjetischen Gräberkommission und der Lokalverwaltung aus der unmittelbaren Nachkriegszeit nennen zwischen $44^{13}$ und 350 sowjetische Kriegsgefangene, die in Gudendorf während des Krieges verstarben und dort begraben wurden ${ }^{14}$. In den Kreisen Segeberg und Süderdithmarschen starben zwischen Sommer 1942 und Kriegsende die meisten sowjetischen Kriegsgefangen in ganz Schleswig-Holstein und Hamburg, was mit der Lage der Orte der erweiterten Krankenreviere in Heidkaten und Gudendorf in diesen Kreisen zu erklären ist ${ }^{15}$

Forschungsergebnisse“, in Dithmarschen. Landeskunde, Kultur, Natur, Heft 3 (September 2004) (Heide: Boyens Medien, 2004), 76.

13 "Schreiben der Zonal Executive Offices an die Headquarter der Länder in der britischen Zone vom 31.08.1949 über die Instandhaltung der sowjetischen Gräber in der britischen Zone", National Archives UK, FO 1006/224, folio 72 A; Lageplanskizze des Ehrenmals in Gudendorf des Kreisbauamtes Meldorf vom 19.08.1958, Kopie in der privaten Sammlung von Helmut Hahn; Anlagen zum Schreiben des vom 19.08.1958, Kopie in der privaten Sammlung von Helmut Hahn; Anlagen zum Schreiben des
Kreisbauamtes Meldorf an den Innenminister des Landes Schleswig-Holstein vom 25.08.1958, Akten Kreisbauamtes Meldorf an den Innenminister des Landes Schleswig-Holstein vom 25.08.1958, Akten
des Innenministeriums Schleswig-Holstein, Kopien in der privaten Sammlung von Helmut Hahn und Martin Gietzelt.

14 Staatliches Archiv der Russischen Föderation (GARF), f. 7317 , op. 21, d. 4, bl. 171-193, insb. BI. 192-193; „Amtsbezirk Südermeldorfgeest, Kreis Süderdithmarschen, Abschrift der Graeberaufstellung über russische Militärpersonen, die auf dem Friedhof in Gudendorf beerdigt sind ca. 1949", Arolsen Archives, ITS 2.2.0.1 / 82429200; „Schreiben betreffend “Erfassung aller russischen Gräber" des Amtsvorstehers für Südermeldorfgeest an den Oberkreisdirektor der Landkreisverwaltung des Kreises Süderdithmarschen vom 06.05.1946", Landesarchiv Schleswig-Holstein, Abtl. 320 Süderdithmarschen, nr. 5854. Ich danke Natalja Jeske für die Unterstützung bei den Recherchen im Süderdithr.
GARF.

${ }^{15}$ Reimer Möller, „Gerhard Hoch und die Erforschung des Schicksals sowjetischer Kriegsgefangener. Eine Auswertung der Gresko-Liste der Roten Armee vom 9. November 1945", in Vom HJ-Führer zum NS-Forscher: Gerhard Hoch: Leben und Werk, Rezeption und Wirkung (Kaltenkirchen: Akens, 2018), 9; Schreiben vom Leiter der Abteilung Erstaufnahme und Erfassung in der Verwaltung des Bevollmächtigten der UdSSR in Sachen der Repatriierung der Bürger der UdSSR, Oberst Gresko, an Bevollmächtigten der UdSSR in Sachen der Repatrilerung der Bürger der UdSSR, Oberst Gresko, an
Generalmajor Šavelskoj, Leiter der Abteilung für die Erfassung der verstorbenen oder verschollenen Mannschaftsdienstgrade oder Sergeanten sowie die Rentenansprüche für ihre Familie, mit einer Liste über im Bereich des Stalags X A verstorbene sowjetische Kriegsgefangene vom 09.11.1945, ОБД Мемориал, accessed April 28, 2020, https://obd-memorial.ru/html/info.htm?id=73574577\&p=1. 


\section{Geschichtspolitik und Erinnerungskultur: Erinnerungspraktiken und} Denkmäler für sowjetische Kriegsgefangene in Gudendorf

In Gudendorf lassen sich drei Phasen von erinnerungskulturellen Bemühungen unterscheiden. In der ersten Phase in der frühen Nachkriegszeit von 1945 bis 1949 übten vor allem die Besatzungsmächte neben den lokalen Akteuren aus Süderdithmarschen und Schleswig-Holstein maßgeblichen Einfluss aus. In der zweiten Phase ab der Gründung der Bundesrepublik Deutschland im Jahre 1949 waren es vor allem die Bundesregierung, das Land Schleswig-Holstein und der Volksbund Deutsche Kriegsgräberfürsorge, die die Erinnerungskultur durch Umbettungen und Neugestaltung der Gudendorfer Grabanlage zur zentralen Grab- und Gedenkanlage für sowjetische Kriegsgefangene in Schleswig-Holstein prägten. Ab den 1980erJahren setzte sich die Graswurzelbewegung „Initiative Blumen für Gudendorf", die sich größtenteils aus Anhängerinnen und Anhängern der Friedensbewegung zusammensetzte, für ein Gedenken am Ort am 8. Mai ein.

\section{Erstes Denkmal ab 1945}

Der politische Kontext war für die Bemühungen der verschiedenen Akteure entscheidend. Für die erste Phase zeigt sich folgendes Bild: Bis 1949 gehörte Schleswig-Holstein zur britischen Besatzungszone, und sowjetische Kommissionen bereisten das Land und inspizierten Grabanlagen sowjetischer Bürgerinnen und Bürger. Sie initiierten unter Rückgriff auf internationale Bestimmungen die ersten Denkmäler auf größeren Grabanlagen in der Nachkriegszeit. Diese waren vornehmlich geprägt vom geschichtspolitischen Narrativ der Sowjetunion, wobei von „sowjetischen Bürgern, die in faschistischer Gefangenschaft starben“, die Rede war, nicht jedoch von Kriegsgefangenen. Einzelne Personen wurden nicht benannt.

Vermittelte „Geschichtsbilder" und ,geschichtspolitische“ Narrative finden sich beispielsweise in der materiellen Gestaltung und Inschriften der frühen Denkmäler. Aus Erläuterungen im Bericht des Chefs der sowjetischen Repatriierungsmission in Schleswig-Holstein, Oberstleutnant Šapovalov, an Oberst Brjuchanov, Chef der sowjetischen Repatriierungsmission in der britischen Besatzungszone, ergibt sich, dass das Denkmal in Gudendorf zwischen August 1945 und Juni 1946 errichtet worden sein muss, bis Oktober 1946 jedoch immer noch nicht endgültig fertiggestellt war ${ }^{16}$. Es war 2,5 Meter hoch, aus Backstein gemauert und die Größe des Sockels betrug 2,5 mal 2,5 Meter. Darum gruppierten sich etwa 40 Grabhügel. Die gesamte Fläche von etwa 50 Quadratmetern wurde von einem Wall umgeben,

${ }^{16}$ GARF, f. 9526, op. 6, d. 255, Bl. 81-82. auf dem eine Hecke nordischer Vogelbeeren angelegt war ${ }^{17}$. Auf der Fotografie ist zudem über der Inschrift ein fünfzackiger sowjetischer Stern zu erkennen $^{18}$.

Nach einem Schreiben des sowjetischen Verbindungsoffiziers Kornjuchin vom 21. April 1949 sollten die Inschriften entsprechend der allgemeinen Vorlage wie folgt lauten: „Здесь захоронено ... советских граждан погибших в фашисткой неволе 1941-1945 гг.“ („Hier liegen ... sowjetische Bürger begraben, die in faschistischer Gefangenschaft in den Jahren 1941-1945 starben.“) ${ }^{19}$. Eine ähnliche Inschrift fand sich auf dem großen Grabstein der Grabanlage in Büdelsdorf: „Здесь захоронено 29 советских граждан погибших в фашисткой неволе 1941-1945 гг.“20 Dass die Inschrift auf dem Ehrenmal in Gudendorf tatsächlich entsprechend formuliert war, zeigt eine überlieferte Fotografie ${ }^{21}$.

Laut Inschrift sollte das Denkmal nicht an einzelne Personen erinnern, sondern an alle dort verstorbenen Opfer, wobei diese allgemein als „sowjetische Bürger, die in faschistischer Gefangenschaft starben“ und nicht spezifisch als Kriegsgefangene bezeichnet wurden. Diese Gestaltung stand ganz im Einklang mit dem Vorgehen der sowjetischen Behörden bei der Errichtung von Denkmälern in der gesamten britischen sowie sowjetischen Besatzungszone. Jens Nagel unterstrich, dass die „Nachkriegsgestaltung der Friedhöfe nur als bewusste Entscheidung gegen ein individuelles wie auch kollektives Gedenken an die Opfergruppe der sowjetischen Kriegsgefangenen interpretiert werden" kann ${ }^{22}$. Im Schriftverkehr der britischen Militärregierung wird diese Gruppe hingegen konkret benannt und für Gudendorf eine Anzahl von etwa 40 Bestatteten angegeben. Im Schreiben der britischen Militärverwaltung im Land Schleswig-Holstein in Kiel an die regionale

${ }_{17}$ Klaus Alberts, Gedenkstätte Gudendorf, von der Architekten- und Ingenieurkammer SchleswigHolstein (Broschüre ohne Verlagsort und Verlag herausgegeben,1995), 12; „Schreiben der Zonal Executive Offices an die Headquarter der Länder in der britischen Zone vom 31.08.1949 über die Executive Offices an die Headquarter der Länder in der britischen Zone vom 31.08.1949 über die
Instandhaltung der sowjetischen Gräber in der britischen Zone“, National Archives UK, FO 1006/224, folio 72 A. Siehe auch Lageplanskizze des Ehrenmals in Gudendorf des Kreisbauamtes Meldorf vom 19.08.1958, Kopie im Privatarchiv von Helmut Hahn.

${ }^{18}$ Fotografie des Ehrenmals auf der Grabstätte für sowjetische Kriegsgefangene in Gudendorf zwischen 1945 und 1958, Privatarchiv Benno Stahn.

19 "Schreiben von Major Kornjuchin vom 21.04.1949“, National Archives UK, FO 1006/224, S. 2. Die erste Seite des Schreibens ist nicht überliefert.

20 "Fotografie der Grabanlage in Büdelsdorf, 1945-1950", National Archives UK, FO 1006/224.

${ }^{21}$ Fotografie des Ehrenmals auf der Grabesstätte für sowjetische Kriegsgefangene in Gudendorf zwischen 1945 und 1960, private Sammlung Benno Stahn.

22 Jens Nagel, „Gefallen-Gefangen-Begraben. Kriegsgräberstätten sowjetischer Kriegsgefangener seit 1945 ", InternationalAssociationofResearchInstitutesintheHistory of Art:RIHAJournal, accessedAugust 9 , 2018, https://www.riha-journal.org//articles/2017/0150-0176-special-issue-war-graves/0175-nagel. 
Militärregierungsbehörde vom 13. Januar 1947 heißt es diesbezüglich: „The burial ground is one for all Russian nationals who died as prisoners of war or concentration camp victims in that area; the number interred is approximately 40 “23.

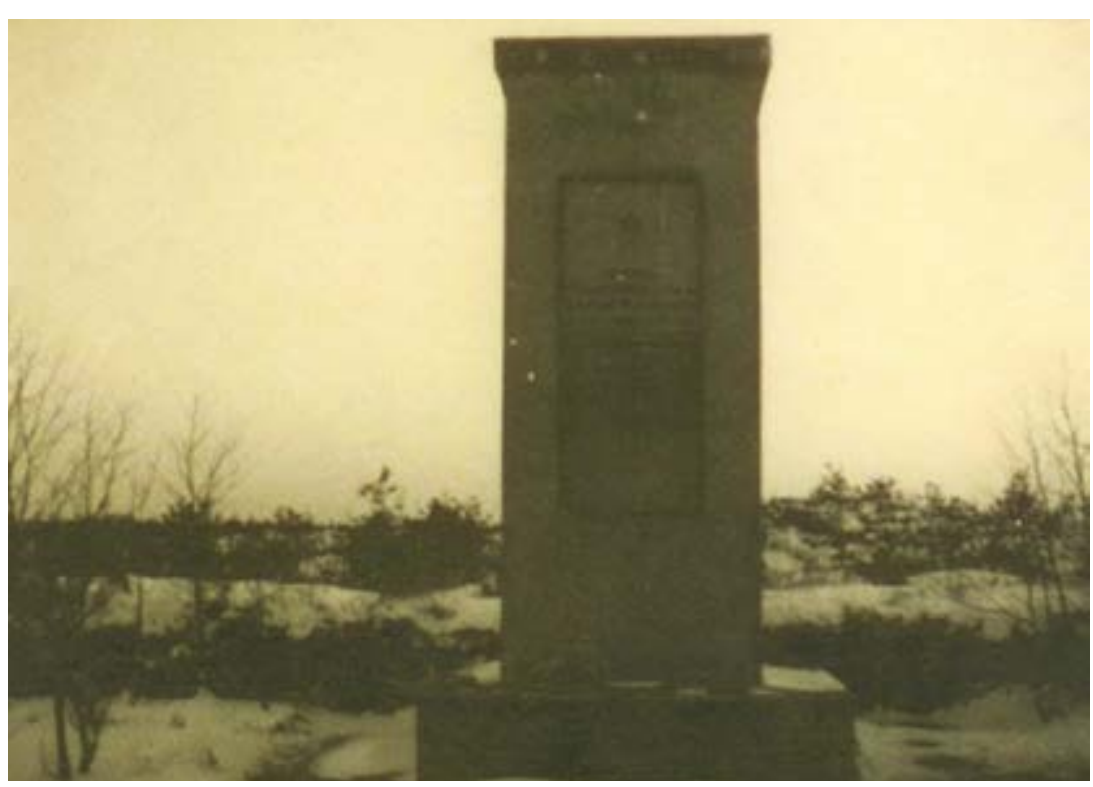

Abb. 1: Foto des Ehrenmals auf der Grabstätte für sowjetische Kriegsgefangene in Gudendorf zwischen 1945 und 1958, private Sammlung von Benno Stahn.

Um die Gestaltung der Inschriften gab es jedoch eine Diskussion zwischen der sowjetischen Kommission, der britischen Besatzungsmacht und der Lokalverwaltung. Dabei ging es vor allem um die Formulierung in Bezug auf die Wehrmacht, die zuständig für die Behandlung der sowjetischen Kriegsgefangenen während der Gefangenschaft war. So äußerte das Ministerium des Inneren des Landes Schleswig-Holstein gegenüber der Kontrollkommission der britischen Militärregierung in Kiel am 14. Juni 1949 folgende Kritik an den Vorschlägen der sowjetischen Repatriierungskommission für die Inschriften:

Objections [...] have been made by the Kreise and Kreis-free towns pointing out that such a wording is irreconcilable with the object proclaimed by all nations participating in the late war, to attain reconciliation among

${ }_{23}$ "Schreiben der Zentrale der britischen Militärverwaltung im Land Schleswig-Holstein in Kiel an das Regional Government Office vom 13.01.1947“, National Archives UK, FO 1006/223, folio 10 A. the peoples, and that it is a „conditio sine qua non“ in pursuance of such efforts to avoid any conduct detriment to the feelings inherent in a nation's honour. Their proposal is that the stone slabs, to be placed in greater cemeteries and charged to the Land Government, should bear the following inscription: „Herunder rest ... Soviet citizens who died in German captivity during the period from 1941 to 1945 “24.

Aus dieser Kritik geht vor allem der Wunsch hervor, die Formulierung „in faschistischer Gefangenschaft “ durch ,in deutscher Gefangenschaft" zu ersetzen. Begründet wurde dieser Begriffswechsel von Seiten des Landesinnenministeriums unter anderem mit dem Verweis darauf, dass das Ziel der Versöhnung unter den Völkern nur erreicht werden könne, wenn das Ehrgefühl keines Landes verletzt würde.

Diese Auseinandersetzung um die Gestaltung der Inschriften auf den Denkmälern zeigt deutlich, dass zwei unterschiedliche Gedenkkulturen bei der Formulierung der Inschriften leitend waren - zum einen diejenige der Sowjetunion, die sich als Antipode des Faschismus verstand, und zum anderen diejenige der Länder Schleswig-Holstein und Niedersachsen, welches vom Geiste des Neubeginns nach dem Krieg geprägt war und das deutsche Ehrgefühl nicht durch Inschriften verletzt sehen wollte. Gleichzeitig kann die Kritik des Landesinnenministeriums auch dahingehend ausgelegt werden, dass es einer kommunistischen Deutung der jüngsten Vergangenheit verhindern wollte. Es gab zudem Unstimmigkeiten darüber, in welcher Sprache die Inschrift verfasst werden sollte, welche die britische Militärregierung folgendermaßen beschied: „In view of the objections taken to the wording to be inscribed on the stone slabs erected in the larger cemeteries, it was agreed that the best solution would be for the inscription to be in Russian" 25 .

Als sich der politische Kontext änderte und der Konflikt zwischen Ost und West stärker wurde, wirkte sich das veränderte Verhältnis zwischen den britischen und sowjetischen Besatzungsmächten auch auf die Erinnerungskulturen aus. Ab Frühjahr 1947 beschuldigten sowjetische Behörden die britische Besatzungsmacht, dass sie Schändungen von sowjetischen Grabanlagen geduldet habe und einen allgemein schlechten Zustand der sowjetischen Grabanlagen hinnehme ${ }^{26}$. In vier Orten konnte ein mutmaßlicher ${ }^{24}$ „Schreiben des Ministeriums des Inneren des Landes Schleswig-Holstein an die Control Commission
der britischen Militärregierung in Kiel am 14.06.1949“, National Archives UK, FO 1006/224.
${ }^{25}$ „Schreiben des Regional Commissioners des Landes Schleswig-Holstein Chetwynd in den
Headquarters der britischen Militärverwaltung im Land Schleswig-Holstein in Kiel an das Innenministerium
der Landesregierung Schleswig-Holstein vom 20.06.1949“, National Archives UK, FO 1006/224.
${ }^{26}$ „Übersetzung eines Schreibens von General Konovalov, Head of the Mission of the Soviet
Commander in Chief to the British Forces of Occupation in Germany, an den Chief Liaison Officer, 
Vandalismus durch die deutsche Bevölkerung, z.B. in Form von Entfernungen des sowjetischen Sterns und der Inschriftenplatten im Frühjahr 1946, durch die britische Militärregierung bestätigt werden. In anderen Orten sei der schlechte Zustand jedoch auf Witterungsschäden zurückzuführen. Von der britischen Militärregierung wurden dann in der ersten Jahreshälfte von 1948 Maßnahmen - nach zunehmenden Druck durch die sowjetischen Behörden - zur würdigen Instandhaltung der Gräber durch die deutschen Kommunen ergriffen ${ }^{27}$.

Während dieser Konflikt zunächst über diplomatische Schreiben ausgetragen wurde, brachten ihn die sowjetischen Behörden im Mai 1948 mit einem Artikel in der sowjetischen Armeezeitung „Krasnaja Zvezda“ ( „,Roter Stern") in eine größere Öffentlichkeit. Nach einer von den britischen Besatzungsbehörden angefertigten Übersetzung hieß es in dem Artikel:

The memory of those who lost their lives in the struggle against fascism, is dear to the peoples of the whole world. The people has [sic] displayed special concern for the graves of Soviet citizens, who fell in battle against the German occupying forces or were tortured to death in Nazi concentration camps. Thousands of patriots in France, Czechoslovakia, Norway, Denmark and other European states were full of admiration for the heroism of the Soviet people who fought for the liberation of their countries. [...]

It is for this reason that all who honour the memory of those who fell in the straggle [sic] against German fascism are deeply indignant at the desecration of the graves of Soviet citizens, which is at present taking place in the British zone of Germany.

In the territory of this zone there are over 500 places in which tens of thousands of Soviet citizens are buried, who were the victims of Nazi concentration camps and of forced labour in German factories. In the years 1945-46111 monuments were erected on their graves and further monuments were planned.

But the fascist monstors [sic] began, with the connivance of British military authorities, to desecrate the graves of Soviet troops ${ }^{28}$.

Mit diesem an eine breitere Öffentlichkeit gerichteten Text warf Oberstleutnant Belyaev der britischen Militärregierung vor, im Gegensatz zu

Brigadier Carthew, vom 21.03.1947“, National Archives UK, FO 371/5427, folio 8; „Übersetzung des Schreibens vom sowjetischen Außenministerium vom 29.04.1947", National Archives UK, FO 371/5427, folio 4 und FO 1049/978.

${ }^{27}$ „Schreiben der Britischen Botschaft in Moskau, no. 584, undatiert", National Archives UK, FO 1081/1030/30.

28 "Übersetzung des Artikels "Desecration of Soviet Memorials" aus dem "Red Star" vom 29.05.1948", National Archives UK, FO 1049/1288. anderen Ländern nicht die Verdienste der gefallenen Rotarmisten zu ehren, da sie keine Maßnahmen getroffen hätte, um die Schändung der Grabanlagen durch die deutsche Bevölkerung zu verhindern. Weiterhin wird der britischen Militärregierung im Artikel vorgeworfen, dass dieses Handeln politisch motiviert sei, um die Erinnerung an die Leistungen der Rotarmisten zu tilgen:

This treatment of the graves of Soviet people, who gave their lives for democracy and freedom of the peoples is far from accidental. The fascis pogromists and those who tolerate them are pursuing definite political aims, that of forcing mankind to forget the great achievement of the Soviet people, which freed Europe from the yoke of fascism.

The people of the whole world revere the memory of Soviet people who lost their lives for the great cause. They remember that the Soviet people made great sacrifices for the attainment of victory and showed an example of self-sacrifice and heroism. There is not nor can be any justification for those who permit and encourage the shameful desecration of the graves of Soviet citizens, who fought against fascism ${ }^{29}$.

Aus diesem Vorwurf wird deutlich, dass die Grabanlagen und Monumente dazu dienen sollten, die Größe und Stärke des Vielvölkerstaates Sowjetunion und die großen Opfer der Sowjetunion für die Befreiung Europas vom Faschismus hervorzuheben.

Dieses Narrativ steht in starkem Kontrast zur sowjetischen Haltung gegenüber repatriierten ehemaligen Kriegsgefangenen und ihrer Sicht im eigenen Land. Die Repatriierten wurden nach ihrer Rückführung in die Heimat als „Vaterlandsverräter“ stigmatisiert und in sogenannten Filtrationslagern des Volkskommissariats für Innere Angelegenheiten (Народный комиссариат внутренних дел, NKVD) auf eine mögliche Kollaboration mit dem Deutschen Reich überprüft und, wenn der Verdacht als erhärtet betrachtet wurde, erneut inhaftiert. Pavel Polian spricht deswegen von „Opfern zweier Diktaturen“"30. Diese Haltung erklärt ebenfalls, warum die Kriegsgefangenen in den Inschriften kollektiv als „sowjetische Bürger, die in faschistischer Gefangenschaft verstarben", bezeichnet wurden und weder Personen mit Namen noch allgemein ihr Status als Kriegsgefangene genannt wurde. Das gegenläufige Geschichtsbild im Artikel des „Roten Stern“ steht in engem Zusammenhang mit der diplomatischen Auseinandersetzung um die Schändung der Grabanlagen und verdeutlicht, wie Akteure des 29 "Übersetzung des Artikels "Desecration of Soviet Memorials"“.

${ }^{30}$ Pavel Polian, Deportiert nach Hause. Sowjetische Kriegsgefangene im „Dritten Reich" und ihre Repatriierung (München: Oldenbourg, 2001); Ulrike Goeken-Haidl, Der Weg zurück. Die Repatriierung sowjetischer Zwangsarbeiter und Kriegsgefangener während und nach dem Zweiten Weltkrieg (Essen: Klartext, 2006). 
öffentlich-politischen Lebens eine Deutung von Geschichte zu politischen Zwecken nutzen.

Das Interesse der deutschen Regierung und schleswig-holsteinischen lokalen Behörden an den sowjetischen Grabanlagen und Denkmälern in den frühen Nachkriegsjahren wurde damit begründet, dass sie sich eine Aufrechterhaltung von Gräbern deutscher Soldaten und Kriegsgefangener in der Sowjetunion erhofften. Dies wird zum Beispiel in einem Schreiben des Kreis Resident Officers aus dem Landkreis Norderdithmarschen, Ronald N. Sinclair, an die Landesregierung in Kiel von Ende Juni 1949 deutlich: „Since the visit there have been requests from the public to know about German graves in Russia and Poland, and also several rumors that people have heard that mass graves had been flattened out and that dances and circuses were performed upon them" ${ }^{31}$. Ähnlich berichtete auch die Tageszeitung „Hamburger Echo“ am 21. Juni 1949 über Gräber von sowjetischen Kriegsgefangenen im Kreis Steinburg und in Itzehoe:

Die Blumen waren nicht genug

Wir berichteten, dass russische Offiziere die russischen Kriegsgräber im Kreise Steinburg besichtigten. Obwohl nach deutscher Ansicht diese Gräber in Ordnung sind, hatte ein russischer Major an ihnen viel auszusetzen. In Itzehoe fehlten bei einigen Gräbern die Kreuze, bei anderen wären die Blumen nicht gut genug. Er erklärte, er werde im August wiederkommen, dann müssten diese Mängel behoben sein. Der Bürgermeister solle es bezahlen. Es wäre schön, wenn in Russland die Gräber deutscher Soldaten einer gleichen Beschauung unterzogen würden. Die dortigen Mängel liessen sich allerdings nicht bis zum August beheben ${ }^{32}$.

\section{Ausbau zur zentralen Gedenkstätte in Schleswig-Holstein ab 1952}

Eine neue Phase der „Geschichtspolitik“ und erinnerungskultureller Bemühungen kann für die Zeit ab 1949 ausgemacht werden, als die Erinnerungsarbeit vor allem durch die Bundesregierung und die schleswig-holsteinische Landesregierung sowie den Volksbund Deutsche Kriegsgräberfürsorge geprägt und Gudendorf zum zentralen Gedenkort in Schleswig-Holstein wurde. Überlegungen zu Umbettungen von vereinzelten Kriegsgräbern mit dem Ziel der Zentralisierung auf wenige Orte gab es im Herbst 1952 auf Landesebene in Schleswig-Holstein. Auf Initiative der Abteilung II Landesplanung in der Staatskanzlei bereisten im September 1956 Vertreter und Vertreterinnen dieser Abteilung, die Geschäftsführerin des Landesverbands

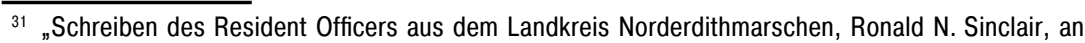
die "Landesregierung in Kiel vom 27.06.1949", National Archives UK, FO 1006/224, S. 2.

32 „Abschrift und Auszug aus dem "Hamburger Echo" vom 21.06.1949", National Archives UK, FO 1006/224.
Schleswig-Holstein des Volksbundes Deutscher Kriegsgräberfürsorge e.V. und ein Regierungs-Baurat „,als Berater für die Ausgestaltung von Ehrenmälern“ den Kreis Süderdithmarschen, um zu prüfen, ob Kriegsgräberanlagen dort zusammengefasst werden könnten. Gudendorf wurde als ein solcher zentraler Ort zur Zusammenfassung von Grabanlagen verstorbener Sowjetbürgerinnen und -bürger ins Auge gefasst trotz des bis dato schlechten Zustandes der Grabanlage. Das Landesinnenministerium konstatierte im September 1956, dass die Anlage in Gudendorf nur ein Provisorium darstelle, das mit den in den ersten Nachkriegsjahren zur Verfügung stehenden, geringen Mitteln geschaffen worden sei. Durch Umbettungen sollte diese Anlage dann ausgebaut werden ${ }^{33}$

Im November 1960 wurden die Exhumierungen und Umbettungen der Kriegsgefangenen abgeschlossen. Insgesamt 248 sowjetische Kriegsgefangene waren aus ganz Schleswig-Holstein nach Gudendorf gebracht worden $^{34}$. Laut Kriegsgräberliste vom 10. November 1960 wurden 94 verstorbene sowjetische Kriegsgefangene von Eggebeck (Kreis Flensburg), 115 aus Broweg in Lindholm (Kreis Nordfriesland), 22 aus Dellstedt (Kreis Dithmarschen) und 17 aus Aumühle (Kreis Herzogtum Lauenburg) nach Dithmarschen umgebettet ${ }^{35}$. Anfänglich sollten die Umbettungen vor allem aus Dithmarschen und nächster Umgebung erfolgen, im Laufe der Zeit wurde der geografische Umkreis für Umbettungen nach Gudendorf auf weitere Kreise ausgedehnt ${ }^{36}$.

Im Sommer 1961 wurde die neue Grabanlage durch den Garten- und Landschaftsarchitekten Hanns-Erik Brodersen, den Künstler Siegfried Assmann und ihre Teams weitestgehend fertig gestellt. Der Begräbnisund Gedenkort mit drei kreisförmig angelegten Grabstätten - zwei für die Umgebetteten und einen leer bleibenden Kreis, der symbolisch für die am Ort bereits Bestatteten stehen sollte - sowie einem Denkmal wurde weiter südlich vom ursprünglichen Bestattungsort angelegt. Zweck der zentralen ${ }_{33}$ Schreiben des Innenministeriums vom 11.09 .1956 an den Landrat des Kreises Süderdithmarschen,
Akten des Innenministeriums Schleswig-Holstein. Kopien der Unterlagen aus dem Innenministerium
Schleswig-Holstein finden sich in der privaten Sammlung von Martin Gietzelt.
${ }^{34}$ Schreiben des Innenministeriums Schleswig-Holstein an die Landräte der Kreise Flensburg, Niebüll,
Heide und Ratzeburg vom 05.10.1960, Akten des Innenministeriums Schleswig-Holstein; Schreiben des
Innenministeriums Schleswig-Holstein an den Garten- und Landschaftsarchitekten Hans-Erik Brodersen
vom 23.11.1960, Akten des Innenministeriums Schleswig-Holstein.
${ }^{35}$ Kriegsgräberliste vom Russenfriedhof Gudendorf vom 10.11.1960, ausgestellt vom Innenministerium
Schleswig-Holstein, Akten des Innenministeriums Schleswig-Holstein.
${ }^{36}$ Schreiben des Kreisbauamtes Meldorf an den Innenminister des Landes Schleswig-Holstein vom
25.08 .1958 , Akten des Innenministeriums Schleswig-Holstein, Kopien in der privaten Sammlung von Martin Gietzelt. 
Gedenkorte an Kriegstote in Schleswig-Holstein - neben der Gedenkstätte in Gudendorf für sowjetische Kriegsgefangene wurde auf dem Karberg am Haddebyer Noor im gleichen Zeitraum ein Gedenkort für deutsche Kriegstote und Kriegstote verschiedener Nationen errichtet - waren laut dem Landesinnenministerium Erinnerung und Mahnung: „Dort sollten die Toten - Angehörige der verschiedenen Nationen, Soldaten und Zivilisten, die Opfer des Krieges geworden sind, - in dem ihnen gebührenden würdigen Rahmen dauernde Ruhe finden. Den Toten zur Ehre, den Lebenden zur ständigen Mahnung!“"37. Der Adressatenkreis wurde damit im Vergleich zum ersten Denkmal in Gudendorf ausgeweitet und die deutsche Nachkriegsgesellschaft einbezogen. Erinnerung wurde zudem mit friedenspädagogischen Zielen verknüpft.

Bei dem neugestalteten Denkmal in Gudendorf wurden nationale Symboliken vermieden und Symbole aus der griechischen Mythologie verwendet. Das steinerne Monument ist 10,7 Meter hoch und wird nach oben hin breiter, am Kopfabschluss berträgt die Breite 3,5 Meter. Die bronzene Figurengruppe ist mit 2,4 Metern Höhe größer als lebensgroß gestaltet worden ${ }^{38}$. Vor der natürlichen Erdanhöhung mit dem daraufgesetztem Denkmal und, die Treppenstufen rahmend, wurde eine 5,3 Meter lange Mauer errichtet. Auf der aus der Sichtweise des Betrachters, der frontal auf das Monument zuläuft, linken Seite steht eine steinerne Wand mit Schriftzug: „Здесь покоятся Советские военнопленные 1941-1945“. Auf der rechten Seite ist die deutsche Übersetzung zu lesen: „Hier ruhen sowjetische Kriegsgefangene 1941-1945“. Etwa hundert Meter vor dem Denkmal, am Eingang der Anlage befindet sich eine Mauer mit dem Schriftzug „Ehrenfriedhof Gudendorf".

Der Künstler Siegfried Assmann wählte bewusst keine christliche oder nationalstaatliche Symbolik, sondern bezog sich mit der bronzenen Figurengruppe im Denkmal auf die griechische Mythologie:

Durch eine öhrhafte Öffnung gleitet das Boot. Es ist das stille, schweben-

de Hinübergleiten des im Tode endlich Geborgenen und wird dem lautlosen

Dahinsterben der ungezählten Typhus- und Fleckfieberkranken weitab ihrer Heimat 1943/44 gerecht $^{39}$.

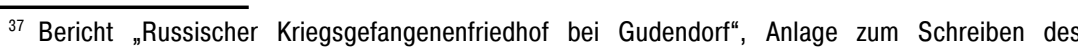
Oberregierungsrates Niewerth an den Volksbund Deutsche Kriegsgräberfürsorge vom 27.07.1961, Akten des Innenministeriums Schleswig-Holstein, Akten.

${ }^{38}$ Bildhauer-Zeichnung zur Gestaltung des Denkmals, Akte von Siegfried Assmann zum „Russenfriedhof Gudendorf", private Sammlung Siegfried Assmann.

${ }^{39}$ Siegfried Assmann, Kiel, 12. Juli - 30. Sept. 1972. Katalog zur Ausstellung des Bildhauers und Malers Siegfried Assmann. Ein Querschnitt aus seinem Schaffen von 1952-1972 (Kiel: Carius Druck, 1972) keine Seitenangaben, Begleittext zu Objektnummer 8.
In einem Zeitzeugengespräch im September 2017 erinnerte sich Siegfried Assmann noch an die Schwierigkeiten bei der Themenwahl zur Gestaltung des Denkmals:

Es war schwierig, das Thema zu fassen, denn die russische Armee oder sowjetische [...] setzt sich ja nicht nur aus Christen zusammen sondern sie sind ja alle ein Konglomerat von Glaubensvereinigungen [...] und [...] so bin ich dann in die Antike gestiegen und das ist von mir verbindlich für alle [...], denn da gibt es ja glaube ich nicht die Trennung zwischen Russen [und anderen] und so habe ich dann den Charon dargestellt, im Kahn wie er über den Styx rudert [...]. Der Tote liegt im Schoß der Mutter ${ }^{40}$.

Die Diversität der Roten Armee zeigt sich tatsächlich in den Quellen zu den in Gudendorf bestatteten sowjetischen Kriegsgefangenen. So war der sowjetische Kriegsgefangene Awelbek Ismailow, 207471 IV B, der im erweiterten Krankenrevier in Gudendorf behandelt wurde und dort am 16. Juni 1944 verstarb, muslimisch ${ }^{41}$. Außerdem finden sich beispielsweise mit Saki Suleimanow $^{42}$ und Mingas Gilfanow ${ }^{43}$ zwei muslimische Tataren unter den von Aumühle nach Gudendorf Umgebetteten sowie ein weiterer namens Gilean Muganow ${ }^{44}$, der ursprünglich in Broweg begraben und 1961 nach Gudendorf umgebettet wurde.

Die Gruppe der hier Bestatteten wird durch die Inschriften des neugestalteten Denkmals spezifischer benannt als zuvor, allerdings geben sie keine Hinweise auf die Umstände des Todes der Gefangenen. Dieser Befund verdeutlicht, dass nämlich Denkmäler keine Aussagen über Inhalte der Geschichte, sondern über deren Aneignung machen. Das kollektive Gedächtnis der frühen BRD war auch 1961 noch stark geprägt von der Schuldbzw. Verantwortungsleugnung der bundesdeutschen Mehrheit. Das daraus resultierende Schweigen drückte sich im Gudendorfer Denkmal darin aus, dass weder die konkreten Todesumstände noch die Verantwortung der

\footnotetext{
$\overline{{ }^{40} \text { Zeitzeugengespräch }}$ mit Siegfried Assmann (geb. am 01.02.1925) vom 15.09.2017.

${ }^{41}$ Siehe: Zentralarchiv des Verteidigungsministeriums der Sowjetunion (CAMO), Abtl. 9, Fondsnr. 58, Inventarnr. 977521, Dateinr. 1348, Erkennungsmarkennummer 209760, Stalag IV В, ОБД Мемориал, accessed January 5, 2019, https://obd-memorial.ru/html/info.htm?id=300614135.

${ }_{42}$ CAMO, Abtl. 9, Fondsnr. 58, Inventarnr. 977528, Dateinr. 55, Erkennungsmarkennummer 118242 , Stalag X В, ОБД Мемориал, accessed February 10, 2020, https://obd-memorial.ru/html/info. htm?id=301120681.

${ }_{43}$ CAMO, Abtl. 9, Fondsnr. 58, Inventarnr. 977520, Dateinr. 2438, Erkennungsmarkennummer 124847 , Stalag X В, ОБД Мемориал, accessed February 10, 2020, https://obd-memorial.ru/html/info. $\mathrm{htm}$ ? $\mathrm{d}=300343499$.

${ }^{44}$ CAMO, Abtl. 9, Fondsnr. 58, Inventarnr. 977521, Dateinr. 1943, Erkennungsmarkennummer 34609, Stalag X D, ОБД Мемориал, accessed February 10, 2020, https://obd-memorial.ru/html/info.
} htm?id=300781059. 
Wehrmacht für den Tod der sowjetischen Kriegsgefangenen in deutscher Gefangenschaft genannt wurden.

Hinzu kam mit dem Ausbau zur zentralen Gedenkstätte eine Revision des Geschichtsbildes in Bezug auf die Opferzahlen, die das Landesministerium stark, nämlich auf 3000 während der Kriegszeit in Gudendorf verstorbene sowjetische Kriegsgefangene, erhöhte. Dies geschah allerdings zunächst nur in der Bedarfsnachweisung für Gelder für die Erhaltung von Kriegsgräbern aus den Jahren 1956 bis $1958^{45}$. Diese Erhöhung sollte nicht nur die hohen Ausgaben für die Gedenkstätte rechtfertigen, sondern ebenfalls auf die besondere Relevanz dieses Gedenkortes verweisen. Dem für den Ausbau der Gedenkstätte verantwortlichen Landesinnenministerium war bewusst, dass Zahlenangaben der bereits in Gudendorf bestatteten und zur Zeit des Krieges verstorbenen sowjetischen Kriegsgefangenen Probleme mit sich brachten. Daher sollten konkrete Zahlenangaben am Gedenkort selbst vermieden werden ${ }^{46}$.

Der für Kriegsgräber verantwortliche Sachbearbeiter im SchleswigHolsteinischen Landesinnenministerium, Oberregierungsrat Niewerth, betonte gegenüber dem Volksbund Deutsche Kriegsgräberfürsorge:

Da wir bewußt genaue Angaben über die Zahl der auf der Ehrenstätte Gudendorf ruhenden russischen Kriegstoten vermeiden (wir sprechen von mehreren Hundert Toten, die im Kriege dort beigesetzt worden sind, und von 248 Kriegstoten, die dorthin umgebettet worden sind), andererseits in dem vorerwähnten Artikel über den Kriegsgefangenenfriedhof bei Gudendorf offen darauf hinweisen, daß das eine Gräberfeld nur den westlichen Teil des alten Gräberfeldes umschließt, auf dem russische Kriegsgefangene während des Krieges beigesetzt worden sind, am Eingang zum Ehrenhof des Friedhofs eine allgemein gehaltenen Widmung angebracht werden wird, auch vorgesehen ist, daß in der Einweihungsrede durch einen allgemeinen Passus auf die Widmung der Ehrenstätte für alle an unbekannter Stelle der Ehrenstätte ruhenden russischen Kriegsgefangenen hingewiesen wird, sollten uns mögliche Fragen der Russen nicht beunruhigen ${ }^{47}$.

${ }^{45}$ Schreiben des Innenministeriums Schleswig-Holstein an das Bundesverwaltungsamt vom 15.11.1960, Akten des Innenministeriums Schleswig-Holstein.

${ }^{46}$ Vermerk des Innenministeriums Schleswig-Holstein vom 29.11.1960, Akten des Innenministeriums Schleswig-Holstein.

${ }^{47}$ Schreiben des Oberregierungsrates Niewerth an den Volksbund Deutsche Kriegsgräberfürsorge vom 27.07.1961, Akten des Innenministeriums Schleswig-Holstein.

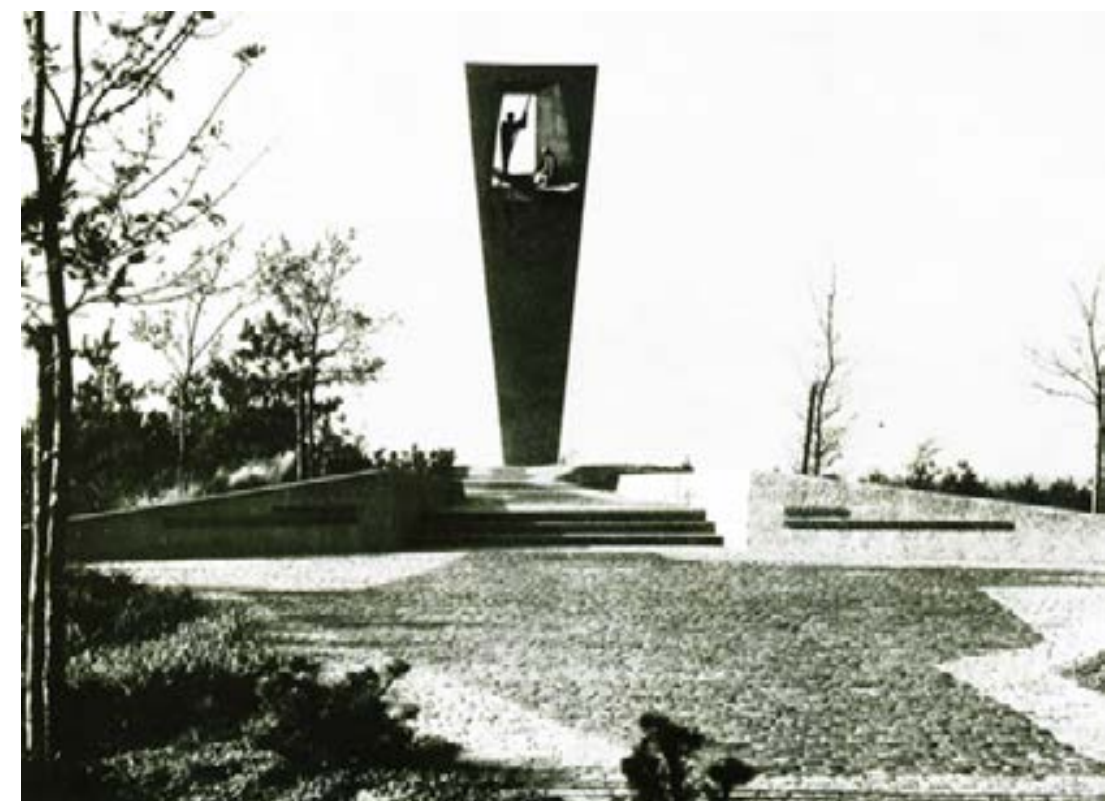

Abb. 2: Aufnahme der Gedenkstätte aus den 1970er Jahren. Abbildungsnachweis: Assmann Siegfried: Kiel, 12. Juli - 30. Sept. 1972. Katalog zur Ausstellung des Bildhauers und Malers Siegfried Assmann. Ein Querschnitt aus seinem Schaffen von 1952-1972, Kiel 1972, keine Seitenangaben, Begleittext zu Objektnummer 8.

Trotzdem wurden über andere Organe wie die lokalen Printmedien Zahlen von 2500 bis 3000 in Gudendorf verstorbenen sowjetischen Kriegsgefangenen verbreitet. In der Husumer Tageszeitung vom 8. August 1961 hieß es zur Fertigstellung der Grab- und Gedenkanlage: „Auf dem Ehrenfriedhof in Gudendorf haben 2500 bis 3000 russische Kriegsgefangenen, die während des zweiten Weltkriegs verstarben, ihre letzte Ruhestätte gefunden. 248 von ihnen wurden aus Gräbern aus dem ganzen Land Schleswig-Holstein im vergangenen Jahr nach hierher umgebettet" ${ }^{\text {48 }}$. Die Norddeutsche Rundschau berichtete am 27. Juli 1962: „Die meisten von ihnen ruhen in Massengräbern, die auch jetzt nicht geöffnet wurden, um sicher zu stellen, daß alle Toten eine würdige Grabstätte haben, hat man das neue Friedhofsgelände sehr groß gehalten“49.

\footnotetext{
${ }^{48}$ Bericht in der Husumer Tageszeitung, nr. 183, vom 08.08.1962, Akten des Innenministeriums Schleswig-Holstein.

${ }^{49}$ "Wird die UdSSR-Botschaft teilnehmen?", Norddeutsche Rundschau vom 27.07.1963, Akten des Innenministeriums Schleswig-Holstein.
} 
Am 7. Dezember 1962 wurde dann schließlich die Bauabnahme durch Vertreter der Bauämter, des Garten- und Landschaftsarchitekten und des Landesinnenministeriums vorgenommen ${ }^{50}$. Von der Einweihungsfeier wurde auf Weisung des Ministerpräsidenten jedoch „vorläufig“ abgesehen und diese auf Frühjahr 1963 verschoben. Das Landesinnenministerium betonte, dass die Einweihung der „Ehrenstätte in Gudendorf [...] ein starkes Politikum" sei. Der genaue Ablauf und inwiefern Vertreterinnen und Vertreter von Bundes- und Landesbehörden, den Kirchen, der Bundeswehr sowie der sowjetische Botschafter beteiligt werden sollten, müsse zunächst noch eruiert werden ${ }^{51}$.

Während die Gedenkstätte für Kriegsopfer verschiedener Nationen am Haddebyer Noor im Sommer 1962 mit einem großen Festakt eingeweiht wurde, trugen Printmedien und Vertreter verschiedener Regierungseinrichtungen gleichzeitig immer stärker Bedenken gegenüber einer Einweihung der Ehrenstätte für sowjetische Kriegsgefangene in Gudendorf vor. Vorbehalte richteten sich vor allem gegen die Teilnahme von Vertretern der sowjetischen Botschaft. Diese Bedenken, die letztlich nicht nur in eine Verlegung, sondern in einen kompletten Verzicht auf eine großangelegte Einweihungsfeier mündeten, hingen stark mit dem Ost-West-Konflikt und insbesondere der sogenannten „Berlin-Krise“ zusammen, die sich in diesen Jahren intensivierten.

Fast zwei Jahre später, im Jahre 1964, wandte sich der Landesverband Schleswig-Holstein des Volksbunds Deutsche Kriegsgräberfürsorge mit der Bitte an das Landesinnenministerium, das Ehrenmal mit einer Feier doch noch einzuweihen, weil er hoffte, dass infolgedessen deutsche Soldatengräber in der Sowjetunion mehr Aufmerksamkeit finden könnten ${ }^{52}$. Das Landesinnenministerium betonte jedoch, dass von Seiten des Landes kein Interesse an einer großen Einweihungsfeier bestünde, „daß außenpolitischen Bedürfnissen aber der Vorrang eingeräumt werden würde" 53 . Das Bundesinnenministerium schlug daraufhin vor, dass „,von einer formellen Einweihungsfeier unter Beteiligung der sowjetischen Botschaft abzusehen“

${ }^{50}$ Schreiben des Innenministeriums Schleswig-Holstein an den Bundesminister des Innern vom 08.05.1964, Akten des Innenministeriums Schleswig-Holstein.

51 Schreiben des Innenministeriums Schleswig-Holstein an den Bundesminister des Innern vom 08.05.1964, Akten des Innenministeriums Schleswig-Holstein.

${ }^{52}$ Schreiben des Volksbundes Deutsche Kriegsgräberfürsorge, Landesverband Schleswig-Holstein, an das Innenministerium Schleswig-Holstein vom 16.04.1964, Akten des Innenministeriums des Landes Schleswig-Holstein; Schreiben des Oberregierungsrates an den Abteilungsleiter I 20 vom 08.04.1964, Akten des Innenministeriums des Landes Schleswig-Holstein.

${ }^{53}$ Schreiben des Oberregierungsrates Niewerth an den Abteilungsleiter I 20 vom 08.04.1964, Akten des Innenministeriums Schleswig-Holstein. sei. Der kommende Volkstrauertag am 15. November 1964 sollte Anlass für eine feierliche Niederlegung von Kränzen der Bundesregierung und der Landesregierung durch einen Vertreter des Auswärtigen Amtes und ein Mitglied der Landesregierung Schleswig-Holstein sein. Von Reden sei dabei abzusehen, aber eine Musikkapelle der Bundeswehr sollte die deutsche und die sowjetische Nationalhymne spielen ${ }^{54}$

\section{Erinnerungskulturelle Praktiken und „Geschichtspolitik“ in Gudendorf im Zweiten Kalten Krieg ${ }^{55}$}

Die Wirkkraft von Geschichtsbildern kann über mehrere Jahrzehnte hinausgehen und auf andere Akteure und Phasen transferiert werden. Dies zeigt sich in der Erinnerungsarbeit der Initiative „Blumen für Gudendorf“ seit den 1980er-Jahren. Zwischen den 1960er- und 1980er-Jahren engagierten sich vereinzelt Schulklassen und regionale Gruppen der „Vereinigung der Verfolgten des Naziregimes - Bund der Antifaschistinnen und Antifaschisten“ zum Beispiel durch Kranzniederlegungen für ein Gedenken vor Ort.

Am 12. Dezember 1979 beschlossen die Außen- und Verteidigungsminister der NATO-Mitgliedstaaten, 108 Pershing-II-Raketen und 464 bodengestützte Marschflugkörper mit Atomsprengköpfen in Westeuropa zu stationieren - als Reaktion auf die Stationierung von SS-20 Raketen durch die Sowjetunion. Darüber hinaus sollten die Supermächte Verhandlungen führen, um die Anzahl atomarer Mittelstreckenraketen in Europa zu begrenzen. Der Deutsche Bundestag stimmte diesem NATO-Beschluss im November 1983 zu, sodass bereits im Folgemonat neue Atomraketen in der BRD aufgestellt wurden. Dieses Aufrüsten erzeugte Angst vor einem bevorstehenden Krieg ${ }^{56}$. In dieser angespannten außenpolitischen Lage entstand Anfang der 1980er-Jahre eine breite Friedensbewegung, welche die bis dahin größten Massendemonstrationen in der Geschichte der Bundesrepublik organisierte $^{57}$.

${ }_{54}$ Vermerk des Innenministeriums Schleswig-Holstein vom 21.09.1964, Akten des Innenministeriums Schleswig-Holstein; Schreiben des Bundesinnenministeriums an das Innenministerium SchleswigHolstein, vom 24.06.1964, Akten des Innenministeriums Schleswig-Holstein, Kopie in der privaten Sammlung von Martin Gietzelt.

${ }^{55}$ Vgl. zum größeren politischen Kontext des „Zweiten Kalten Kriegs“ von Ende der 1970er bis Mitte der 1980er Jahre: Philipp Gassert, Tim Geiger, und Hermann Wentker (Hgg.). „Zweiter Kalter Krieg und Friedensbewegung: Einleitende Überlegungen zum historischen Ort des NATO-Doppelbeschlusses von 1979", in Zweiter Kalter Krieg und Friedensbewegung. Der NATO-Doppelbeschluss in deutschdeutscher und internationaler Perspektive (München: Springer, 2011), 7-30.

${ }^{56}$ Gassert, Geiger, und Wentker (Hgg.). „Zweiter Kalter Krieg“, 7.

${ }^{57}$ Gassert, Geiger, und Wentker (Hgg.). „Zweiter Kalter Krieg“, 8. 
Die politischen Debatten dieser Zeit spielten eine zentrale Rolle bei der Initiierung von Gedenkveranstaltungen am Denkmal für die sowjetischen Kriegsgefangenen in Gudendorf. Die Initiative „Blumen für Gudendorf“ entstand in engem Zusammenhang mit der Friedensbewegung, auch wenn unterschiedliche Akteure mit verschiedenen Motiven beteiligt waren. Vorherrschend war jedoch der Wunsch, für Entspannung und Abrüstung einzutreten $^{58}$. Als Projektionsfläche wurde der Erinnerungsort in Gudendorf genutzt, um Erinnerung mit Mahnung zu verbinden und für diese politischen Ziele zu werben. Der heutige Sprecher der Initiative Benno Stahn erinnert sich an den politischen Aktivismus in den 1980er-Jahren:

Da hat man jede Möglichkeit gesucht, in die Öffentlichkeit zu gehen und zu sagen, also Russland, das haben wir schon zweimal versucht, ein drittes Mal wird [man] das nicht überleben. Und [...] wir wollten tatsächlich den Krieg verhindern. Das war der Nenner, der uns von Kommunisten bis Christen geeint hatte ${ }^{59}$.

Gerade solche lokalen Aktionen waren ein Kennzeichen der Friedensbewegung neben den großen, zentralen Demonstrationen in Bonn, Hamburg, Berlin und anderen Städten ${ }^{60}$.

Die erste Gedenkveranstaltung in Gudendorf wurde am 8. Mai 1984 abgehalten. Hans Motzner hielt eine kleine Ansprache. Er selbst war als deutscher Kriegsgefangener in der Sowjetunion in einem Kriegsgefangenenlager gewesen, dort jedoch laut eigenen Aussagen human behandelt worden, weswegen es wichtig sei, sich für ein Gedenken an das Leid der sowjetischen Kriegsgefangene in deutscher Gefangenschaft einzusetzen ${ }^{61}$. In Folge der Erfahrungen dieser ersten Gedenkveranstaltung wurde beschlossen, in $\mathrm{Zu}$ kunft jährlich Gedenkveranstaltungen zum 8. Mai in Gudendorf abzuhalten. Dazu sollten weitere Unterstützerinnen und Unterstützer gewonnen werden.

In diese Zeit fiel außerdem der Beschluss, sich Initiative „Blumen für Gudendorf“ in Anlehnung an den Arbeitskreis „Blumen für Stukenbrock“

\footnotetext{
${ }^{58}$ Andreas Buro, „Friedensbewegung", in Die Sozialen Bewegungen in Deutschland seit 1945: Ein Handbuch, hrsg. von Roland Roth und Dieter Rucht (Frankfurt a. M.: Campus, 2008), 268.

59 Zeitzeugengespräch mit Benno Stahn und weiteren Mitgliedern der Initiative „Blumen für Gudendorf“ vom 26.10.2018.

${ }^{60}$ Christoph Becker-Schaum, „Einleitung. Die Nuklearkrise der 1980er Jahre. NATO-Doppelbeschluss und Friedensbewegung", in "Entrüstet euch!" Nuklearkrise, NATO-Doppelbeschluss und Friedensbewegung (Paderborn: Schöningh, 2012), 18f.

${ }^{61}$ Becker-Schaum, „Einleitung", 18f.
}

zu nennen ${ }^{62}$. Dieser Arbeitskreis hatte sich bereits 1967 gegründet, um dem ehemaligen Kriegsgefangenlager 326 (VI K)zu gedenken ${ }^{63}$.

Gemeinsam traten diese zivilgesellschaftlichen Zusammenschlüsse nicht nur für politische Ziele wie Abrüstung und ein Ende des Kalten Krieges ein, sondern sie leisteten auch einen wichtigen Beitrag zur Aufarbeitung der nationalsozialistischen Vergangenheit. Ein ähnliches Bild zeigte sich in Kaltenkirchen bzw. Heidkaten, wo sich Aktivisten für ein Gedenken an das Leid der Häftlinge des KZ-Außenlagers von Neuengamme in Kaltenkirchen sowie für die im erweiterten Krankenrevier in Heidkaten verstorbenen sowjetischen Kriegsgefangenen einsetzten. Auch dieses Engagement stand ähnlich wie in Gudendorf und Stukenbrock im Einklang mit der Friedensbewegung. Erste Aufarbeitungen zur nationalsozialistischen Gewaltherrschaft in Schleswig-Holstein leistete in den 1980er-Jahren der Historiker Gerhard Hoch, der sich ebenfalls in Heidkaten und Gudendorf engagierte ${ }^{64}$. Er bezeichnete Gudendorf, wie auch Heidkaten, als „Sterbelager“, und meinte, hier ein „geordnetes Massensterben " nachweisen zu können ${ }^{65}$. Er argumentierte, das Lager Gudendorf habe im Jahre 1944 die Funktion eines „Sterbelagers“" von Heidkaten übernommen ${ }^{66}$. Hoch kam zu dieser Schlussfolgerung vor allem aufgrund von Zeitzeugenaussagen, verfügte jedoch nicht über entsprechende Quellen aus der Lagerverwaltung ${ }^{67}$.

Diese Argumentation ist in zweierlei Hinsicht problematisch. Hoch setzt nicht nur die Lager in Gudendorf und Heidkaten gleich, sondern nimmt ebenfalls die Zahl der 3000 verstorbenen Kriegsgefangenen als gegeben an. Da zu dem Zeitpunkt noch kein Zugang zu den Verlustlisten in sowjetischen Unterlagen bestand, konnte er kein gesichertes Wissen durch weitere Quellenbelege über das Ausmaß der Sterblichkeit erlangen. Er versuchte, die Zahl von 3000 Toten vor allem mit Zeitzeugenaussagen über Heidkaten

${ }_{62}$ Günther Wilke, „Zur Geschichte der Initiative "Blumen für Gudendorf“", in Newsletter Gedenkstätten und Erinnerungsorte in Schleswig-Holstein, nr. 9 (April 2016), 12 (accessed January 11, 2019, http:// www.gedenkstaetten-sh.de/t__files/gedenkstaetten/daten/stiftung/Nr_9_April_2016.pdf).

${ }^{63}$ Siehe: "Geschichtskultur in der Region. Arbeitskreis Blumen für Stukenbrock", Homepage der Universität Bielefeld, accessed January 11, 2019, http://www.uni-bielefeld.de/geschichte/ regionalgeschichte/Kooperationspartner/selbstdarstellung_blumen_fuer_stukenbrock/.

${ }_{64}$ Gerhard Hoch, Zwölf wiedergefundene Jahre. Kaltenkirchen unter dem Hakenkreuz (Bad Bramstedt: Roland Werbung, 1981); Gerhard Hoch, „Erweitertes Krankenrevier in Heidkaten“, in Verschleppt zur Sklavenarbeit. Kriegsgefangene und Zwangsarbeiter in Schleswig-Holstein, hrsg. von Rolf Schwarz (Aveslohe: W. Geffken, 1986), 77-100.

${ }^{65}$ Gerhard Hoch, „Geordnetes Massensterben“, in Dithmarschen 1/1996. Gudendorf: Gefangenenlager und Gedenkstätte (Heide: Boyens, 1996), 3-7.

${ }^{66}$ Hoch, ,Geordnetes Massensterben“, 4.

${ }^{67}$ Hoch, „Geordnetes Massensterben“, 5. Vgl. Hoch, „Erweitertes Krankenrevier in Heidkaten“, 82-86. 
zu rechtfertigen, noch dazu ohne den Überlieferungskontext dieser Zahl zu hinterfragen. Sie wurde erstmals im Zuge der Neugestaltung der Gedenkanlage zu Beginn der 1960er Jahre genannt.

Die Übertragung von Beobachtungen, die auf Heidkaten zutrafen, auf Gudendorf ist insofern problematisch, da es sich um unterschiedliche zeitliche Kontexte und eine damit einhergehende unterschiedliche Behandlung der sowjetischen Kriegsgefangenen handelte. Im Anschluss an Gerhard Hochs frühe Untersuchungen übernahm die Initiative „Blumen für Gudendorf" dieses Bild des Lagers und vermittelte es anfangs bei ihren jährlichen Gedenkveranstaltungen. So hieß es beispielsweise im Aufruf zur „Gedenkkundgebung" am 6. Mai 1989:

An den Massengräbern von mehr als 3000 sowjetischen Kriegsgefangenen und Zwangsarbeitern in Gudendorf bei St. Michaelisdonn wollen wir am 6. Mai 1989 wieder zur Mahn- und Gedenkkundgebung zusammenkommen. Der Tag der Befreiung von Krieg und Faschismus findet diesmal wenige Wochen vor dem Besuch Michail Gorbatschows in der Bundesrepublik statt. Wie begrüßen diesen Besuch und verstehen ihn als Chance, die Verständigung mit der Sowjetunion auf stabile Grundlagen zu stellen.

Die Geschichte erlegt uns die Verpflichtung auf, nachdrücklich für Frieden und Zusammenarbeit einzutreten. Sowjetische Abrüstungsinitiativen zeugen von der Bereitschaft, den Geist der Konfrontation zu überwinden. Wir erwarten von der Bundesregierung, daß sie diese Maßnahmen mit eigenen Schritten für Abrüstung beantwortet und auf die „Modernisierung“ atomarer Raketen in der Bundesrepublik verzichtet ${ }^{68}$.

Jüngere Forschungen wie jene von Martin Gietzelt beziehen mittlerweile Quellen aus Archiven der ehemaligen Sowjetunion ein und können somit das „Geschichtsbild“ vom Sterbelager in Gudenorf mit 3000 Toten revidieren. Gietzelt betont, dass der Begriff und die Zahl nicht haltbar sind, Gudendorf aber durchaus „Teil eines Systems [war], das den Tod der sowjetischen Kriegsgefangenen offen einkalkulierte und für deren Lebensbedingungen nicht menschliche, sondern wirtschaftliche Maßstäbe galten“69.

\section{Schluss}

Das Regionalbeispiel Gudendorf zeigt, dass die Erinnerung an sowjetische Kriegsgefangene dort nicht im „Erinnerungsschatten“ lag, sondern aktiv von verschiedenen Akteuren für eine „Geschichtspolitik“ genutzt wurde. Erinnern ist ein dynamischer Prozess, der vom übergeordneten sozio-politischen Kontext und durch die Erinnerungspraktiken der Akteure 68 „Initiative Blumen für Gudendorf“. Aufruf zur "Gedenkkundgebung“ am 6. Mai 1989, private
Sammlung von Dietrich Stein.

${ }^{69}$ Gietzelt, „Die Gedenkstätte Gudendorf“, 76. beeinflusst ist. Die Errichtung der ersten beide Denkmäler und die Auseinandersetzung der verschiedenen Akteure um dessen Gestaltung und vermittelte „Geschichtsbilder“ korrelierte mit übergeordneten politischen Konflikten wie der Berliner Blockade von Juni 1948 bis Mai 1949, dem Mauerbau 1961 sowie dem NATO-Doppelbeschluss von 1979, welche Höhepunkte der Auseinandersetzungen zwischen Ost und West waren. Die Darstellung der Erinnerungspraktiken in Gudendorf in diesen drei Phasen hat gezeigt, dass die Akteure in jeder Phase eine „öffentliche Repräsentation einer kollektiv relevanten Vergangenheit zu politischen Zwecken“ nutzten und eine Deutung der Vergangenheit in diesem Sinne vornahmen ${ }^{70}$.

Das Land Schleswig-Holstein unternahm mit der Umgestaltung der Grabesstätte in Gudendorf zum zentralen Gedenkort für sowjetische Kriegsgefangene einen erinnerungskulturellen Beitrag, der nicht dem allgemeinen und bundesweiten kollektiven Gedächtnis der Zeit entsprach. Die jährliche Erinnerungsarbeit der Initiative „Blumen für Gudendorf“ im Rahmen jährlicher Gedenkveranstaltungen um den 8. Mai trug dazu bei, dass der „Erinnerungsschatten“ an das Leid der sowjetischen Kriegsgefangenen in deutscher Gefangenschaft auf lokaler Ebene vielleicht weniger stark ausgeprägt war als an vielen anderen Orten der Republik. Das Regionalbeispiel hat jedoch auch gezeigt, dass Denkmäler und Erinnerungspraktiken keine,,Aussagen über Inhalte der Geschichte, sondern über deren Aneignung“ machen ${ }^{71}$. Die vermittelten „Geschichtsbilder" stehen damit in einem starken Bezug zur jeweiligen Gegenwart.

Верена Мейер

\section{МЕМОРІАЛ РАДЯНСЬКИМ ВІЙСЬКОВОПОЛОНЕНИМ У ГУДЕНДОРФІ - ПАМ'ЯТЬ ПІД ЧАС ХОЛОДНОЇ ВІЙНИ}

Доля радянських військовополонених, які представляють другу за величиною групу жертв нацистських злочинів, відіграє лише незначну роль у пам'яті Німеччини. У 2015 році тодішній федеральний президент Йоахім Гаук зазначив, що ия частина історії націонал-соціалізму перебуває в «тіні пам'яті». 3 іншого боку, погляд на регіональний приклад Гудендорфа показує, що там пам'ять про радянських військовополонених не перебувала в «тіні», а активно використовувалася різними діячами для їх «історичної політики». Меморіальні акції, як-от спорудження двох пам'ятників та організація меморіальних заходів, були пов'язані із

\footnotetext{
${ }^{70}$ Schmid, „Konstruktion“, 78

${ }^{71}$ Erben, „Denkmäler“, 235.
} 
соціально-політичним контекстом вищого рівня, який впливав на місиевих діячів.

У цій статті досліджуються «історичні образи», що передаються меморіальними заходами різних дійових осіб, які використовували інтерпретацію історії для досягнення політичних цілей у трьох різних фазах. Дослідження орієнтується на науково-історичну аналітичну таблицю «історичної політики»: На першій фазі (1945-1949) британський військовий уряд та радянська військова комісія спорудили перший меморіал вшанування пам'яті загиблих радянських військовополонених. Другий етап (1949-1983) насамперед характеризувався меморіальнополітичною активністю молодого федерального уряду та уряду землі Шлезвіг-Гольштейн, а також народної спілки Німеччини з догляду за військовими похованнями. У цей період земля Шлезвіг-Гольштейн обрала Гудендорф центральним місцем для перепоховання загиблих радянських військовополонених і вирішила розширити це місце до центрального меморіалу, спорудивши новий пам'ятник, який був завершений у 1961 році. Третю фазу можна спостерігати з 1983 р., коли низова ініціатива «Квіти для Гудендорфу» використовувала меморіал як майданчик для вианування пам'яті радянських військовополонених, які перебували у Нiмеччині під час Другої світової війни, а також для запобігання черговій війні з Радянським Союзом та агітувала за мир. Більшість членів цієі програми були активістами руху за мир, тому перші історичні аналізи та меморіально-культурні заходи поєднувалися з політичною агітацією, пов'язаною з політичною напругою вищого рівня в холодній війні. Спорудження перших двох пам'ятників та суперечка між різними учасниками щодо їх вигляду та передачі «історичних образів» співвідносилися із політичними конфліктами вищого рівня. Тут слід назвати такі кульмінаційні конфліктні моменти між Сходом і Заходом: блокада Берліну з червня 1948 р. по травень 1949 р., спорудження Берлінської стіни з 13 серпня 1961 р. та подвійне рішення НАТО 1979 р.

У статті не лише досліджуються «історичні образи» різних дійових осіб у трьох фазах, які транслювалися громадськості, а й ставиться питання про передачу образів у різних групах учасників та фазах. Боротьба різних дійових осіб за прерогативу інтерпретації історичних образів, які вони транслюють, вивчається у відповідному контексті та аналізуються мотивації різних меморіальних заходів. Можна побачити, наприклад, що на перших двох етапах виникали дискусії щодо вигляду пам'ятників, які в основному стосувались використання національної символіки, найменування групи жертв та обставин загибелі радянських військовополонених у німецькому полоні. У той час як радянська комісія з поховань пропонувала напис, який мав дати зрозуміти, шо радянський народ загинув «у фашистському полоні», деякі кола у Шлезвіг-Гольштейні та Нижній Саксонії вимагали, щоб напис був «у німецькому полоні». Напис на другому пам'ятнику, який був встановлений близько 1960 р. з ініціативи земельного уряду, не дає жодних вказівок на обставини загибелі полонених. Це, у свою чергу, перегукувалось з тим мовчанням та припиненням дебатів щодо власної вини та німецької відповідальності, які панували в ранній Федеративній Республіці.

Напис на першому пам'ятнику все ще описує групу жертв радянських військовополонених як «радянських громадян», тобто їх фактичний статус тут маскується. Цей стиль знову відповідав національному наративу Радянського Союзу, який був насамперед покликаний вщанувати досягнення партизанів та червоноармійців, які визволили Свропу від «фашизму». Народний комісаріат внутрішніх справ розглядав військовополонених як потенційних «зрадників вітчизни» та проводив розслідування щодо репатріантів.

3 розбудовою місия поховання в центральний меморіал радянським військовополоненим у Шлезвіг-Гольштейні та з перепохованням 248 радянських військовополонених з усієї федеральної землі в 1958 році земельне міністерство внутрішніх справ вперше назвало число 3000 радянських військовополонених у Гудендорфі, що значно більше, ніж ті 40-350 загиблих, яких називали союзні окупаційні війська та громада в перші повоєнні роки. Ця кількість, оголошена міністерством, публічно пропагувалася та переказувалася тими діячами, які на третьому етапі докладали зусиль до аналізу та пам'яті про націонал-соціалістичні злочини проти радянських військовополонених. Вони сформували образ «табору смерті» в Гудендорфі, який до сьогодні не втратив сили в популярному меморіально-політичному дискурсі, хоча нові дослідження вже класифікували та спростували цю тезу.

Ключові слова: радянські військовополонені, пам'ятники, радянська комісія з поховань, холодна війна, історична політика.

\section{Verena Meier \\ THE MEMORIAL FOR SOVIET PRISONERS OF WAR IN GUDENDORF - MEMORIES IN THE COLD WAR}

The fate of the Soviet prisoners of war, who represent the second largest victim group of Nazi violent crimes, plays only a marginal role in the memory of Germany. For example, the then Federal President Joachim Gauck pointed out 
in 2015 that this portion of the history of National Socialism lay within a "memory shadow". A look at the regional example of Gudendorf, on the other hand, shows that the memory of Soviet prisoners of war was in no "shadow" but rather was actively used by various representatives for their own "politics of memory".

Based on the analysis grid of "politics of memory", this article investigates the "historical images" of different participants conveyed through the commemorative practices, who used an interpretation of history in three different phases to pursue political purposes: In the first phase from 1945 to 1949, the British military government and the Soviet military commission erected a first memorial to commemorate the deceased Soviet prisoners of war. The second phase from 1949 to 1983 was primarily characterized by the commemorative commitment of the young federal government and the Schleswig-Holstein state government as well as German War Graves Commission. During this period, the state of Schleswig-Holstein chose Gudendorf as the central burial ground for the reburial of dead Soviet prisoners of war and decided to expand the burial ground into a central memorial with a new monument. The third phase can be identified from 1983 on, when the grassroots movement "Flowers for Gudendorf" initiative used the memorial as a platform to commemorate the fate of Soviet prisoners of war in German custody during the Second World War and also to warn of a renewed war with the Soviet Union and campaigned for peace. The majority of the members of this initiative were active in the peace movement, and so the first historical reviews and memorial-cultural methods combined with political agitations related to the overarching political tensions in the Cold War. The erection of the first two monuments and the dispute between the various representatives about their design and mediated "historical images" correlated with the overarching political conflicts, highlighted by the Berlin blockade, the construction of the Berlin Wall and the NATO double decision of 1979.

The article investigates not only the "historical images" of the different participants conveyed to the public in the three phases, but also asks about the transfer of the images across different representative groups and phases. The struggle of the various representatives for the sovereignty of interpreting the historical images they convey is studied in an appropriate context and the motivations of various memorial events are analyzed. It can be seen, for example, that in the first two phases, discussions arose about the design of the monuments, which mainly concerned the use of national symbols, the naming of the victim group and the circumstances surrounding the death of Soviet prisoners of war in German captivity. While the Soviet Burial Commission proposed an inscription to indicate that the Soviet people had died "in fascist captivity", some circles in Schleswig-Holstein and Lower Saxony demanded that the inscription should be "in German captivity". The inscription on the first monument still refers to the group of victims of Soviet prisoners of war as "Soviet citizens", so their actual status is disguised here. This style again corresponded to the national narrative of the Soviet Union, which was primarily intended to honor the partisans and Red Army soldiers who liberated Europe from "fascism". Prisoners of war were viewed as potential "traitors to the motherland". The inscription of the second monument, which was erected around 1960 on the initiative of the state government, does not provide any indication of the circumstances of the prisoners' death. This in turn corresponded to the silence and debates in the early Federal Republic regarding one's own guilt and German responsibility.

With the expansion of the graves into a central memorial for Soviet prisoners of war in Schleswig-Holstein and the reburial of 248 Soviet prisoners of war from across the federal state in 1958, the State Interior Ministry first named 3,000 Soviet prisoners of war who died in Gudendorf in wartime, a far larger number than the 40 to 350 dead who were called the "Allied occupying forces and the community" in the early post-war years. This number, which was named by the ministry, was publicly promoted and retold by those persons who, in the third phase, made efforts to analyze and commemorate National Socialist crimes against the Soviet prisoners of war. They formed the image of the "death camp" in Gudendorf, which until today has not lost any of its power in popular memorial-political discourse, although new research has already classified and refuted this.

Keywords: Soviet prisoners of war, monuments, Soviet graves commission, Cold War, historical policy.

\section{Bibliography}

Alberts, Klaus. Gedenkstätte Gudendorf, von der Architekten- und Ingenieurkammer Schleswig-Holstein. Broschüre ohne Verlagsort und Verlag herausgegeben, 1995.

Assmann, Siegfried. Kiel, 12. Juli - 30. Sept. 1972. Katalog zur Ausstellung des Bildhauers und Malers Siegfried Assmann. Ein Querschnitt aus seinem Schaffen von 1952-1972. Kiel: Carius Druck, 1972.

Becker-Schaum, Christoph. «Einleitung. Die Nuklearkrise der 1980er Jahre. NATO-Doppelbeschluss und Friedensbewegung.» In «Entrüstet euch!» Nuklearkrise, NATO-Doppelbeschluss und Friedensbewegung, 7-37. Paderborn: Schöningh, 2012.

Buro, Andreas. «Friedensbewegung.» In Die Sozialen Bewegungen in Deutschland seit 1945: Ein Handbuch, hrsg. von Roland Roth und Dieter Rucht, 267-292. Frankfurt a. M.: Campus, 2008.

«Donesenija o bezvozvratnyh poterjah.» OBD Memorial, ID73574577, Dokument 1 bis 52. Accessed April 28, 2020. https://obd-memorial.ru/ html/info.htm?id=73574577\&p=1. 
Erben, Dietrich. «Denkmäler.» In Handbuch der politischen Ikonographie, hrsg. von Uwe Fleckner, Martin Warnke und Hendrik Ziegler.Band I, 235-243. München: Beck, 2011.

Gassert, Philipp, Tim Geiger, und Hermann Wentker (Hgg.). «Zweiter Kalter Krieg und Friedensbewegung: Einleitende Überlegungen zum historischen Ort des NATO-Doppelbeschlusses von 1979.» In Zweiter Kalter Krieg und Friedensbewegung. Der NATO-Doppelbeschluss in deutsch-deutscher und internationaler Perspektive, 7-30. München: Springer, 2011.

Gauck, Joachim. «Rede zum 70. Jahrestag des Endes des Zweiten Weltkrieges am 6. Mai 2015 in Schloss Holte-Stukenbrock.» Accessed January 19, 2019. http://www.bundespraesident.de/SharedDocs/Reden/DE/ Joachim-Gauck/Reden/2015/05/150506-Holte-Stukenbrock.html.

«Geschichtskultur in der Region. Arbeitskreis Blumen für Stukenbrock.» Homepage der Universität Bielefeld. Accessed January 11, 2019.http://www. uni-bielefeld.de/geschichte/regionalgeschichte/Kooperationspartner/ selbstdarstellung_blumen_fuer_stukenbrock/.

Gietzelt, Martin. «Die Gedenkstätte Gudendorf. Neue Forschungsergebnisse.» In Dithmarschen. Landeskunde, Kultur, Natur. Heft 3 (September 2004), 57-80. Heide: Boyens Medien, 2004.

Goeken-Haidl, Ulrike. Der Weg zurück. Die Repatriierung sowjetischer Zwangsarbeiter und Kriegsgefangener während und nach dem Zweiten Weltkrieg. Essen: Klartext, 2006.

Hoch, Gerhard. «Erweitertes Krankenrevier in Heidkaten.» In Verschleppt zur Sklavenarbeit. Kriegsgefangene und Zwangsarbeiter in SchleswigHolstein, hrsg. von Rolf Schwarz, 77-100. Aveslohe: W. Geffken, 1986.

Hoch, Gerhard. «Geordnetes Massensterben.» In Dithmarschen 1/1996. Gudendorf: Gefangenenlager und Gedenkstätte, 3-7. Heide: Boyens, 1996.

Hoch, Gerhard. Zwölf wiedergefundene Jahre. Kaltenkirchen unter dem Hakenkreuz. Bad Bramstedt: Roland Werbung, 1981.

«Informacija o voennoplennom.» OBD Memorial. Accessed Fabruary 10, 2020. https://obd-memorial.ru/html/info.htm?id=300343499.

«Informacija o voennoplennom.» OBD Memorial. Accessed January 5, 2019. https://obd-memorial.ru/html/info.htm?id=300614135.

«Informacija o voennoplennom.» OBD Memorial. Accessed Fabruary 10, 2020. https://obd-memorial.ru/html/info.htm?id=300781059.

«Informacija o voennoplennom.» OBD Memorial. Accessed Fabruary 10, 2020. https://obd-memorial.ru/html/info.htm?id=301120681.

Jahn, Peter. «Das Schicksal sowjetischer Kriegsgefangener in der deutschen Erinnerung.» In «Ich werde es nie vergessen». Briefe sowjetischer Kriegsgefangener 2004-2006, 30-35. Berlin: Ch. Links, 2007.
Keller, Rolf. Sowjetische Kriegsgefangene im Deutschen Reich 1941/42. Behandlung und Arbeitseinsatz zwischen Vernichtungspolitik und kriegswirtschaftlichen Zwängen. Göttingen: Wallstein, 2011.

Möller, Reimer. «Gerhard Hoch und die Erforschung des Schicksals sowjetischer Kriegsgefangener. Eine Auswertung der Gresko-Liste der Roten Armee vom 9. November 1945.» In Vom HJ-Führer zum NS-Forscher: Gerhard Hoch: Leben und Werk, Rezeption und Wirkung, 2-15. Kaltenkirchen: Akens, 2018.

Nagel, Jens. «Gefallen -Gefangen - Begraben. Kriegsgräberstätten sowjetischer Kriegsgefangener seit 1945.» International Association of Research Institutes in the History of Art: RIHA Journal. Accessed August 9, 2018. https://www.riha-journal.org//articles/2017/0150-0176-special-issuewar-graves/0175-nagel.

Otto, Reinhard, Rolf Keller, und Jens Nagel. «Sowjetische Kriegsgefangene in deutschem Gewahrsam 1941-1945. Zahlen und Dimensionen.» Vierteljahrshefte für Zeitgeschichte 4 (2008): 557-602.

Polian, Pavel. Deportiert nach Hause. Sowjetische Kriegsgefangene im «Dritten Reich» und ihre Repatriierung. München: Oldenbourg, 2001.

Schmid, Harald. «Konstruktion, Bedeutung, Macht. Zum kulturwissenschaftlichen Profil einer Analyse von Geschichtspolitik.» In Geschichtspolitik und sozialwissenschaftliche Theorie, hrsg. von Horst-Alfred Heinrich und Michael Kohlstruck, 75-98. Stuttgart: Steiner, 2008.

Streim, Alfred. Die Behandlung sowjetischer Kriegsgefangener im «Fall Barbarossa». Heidelberg/Karlsruhe: C. F. Müller, 1981.

Troebst, Stefan. «Geschichtspolitik.» Docupedia. Accessed August 23, 2018. http://docupedia.de/images/1/13/Geschichtspolitik.pdf.

Tschirner, Thomas. "„Kleine Fische“ - Das Schicksal sowjetischer Kriegsgefangener in Schleswig-Holstein. Eine regionale Studie anhand von Personalkarten der im „Erweiterten Krankenrevier Heidkaten“ gestorbenen sowjetischen Kriegsgefangenen, Examensarbeit von 2011», 98. Accessed January 17, 2019. http://www.zwangsarbeiter-s-h.de/Ergebnisse/Tschirner/Sowjetische\%20Kriegsgefangene\%20in\%20S-H.pdf.

Wilke, Günther. «Zur Geschichte der Initiative „Blumen für Gudendorf“.» In Newsletter Gedenkstätten und Erinnerungsorte in SchleswigHolstein, nr. 9 (April 2016), 11-14 (Accessed January 11, 2019. http:// www.gedenkstaetten-sh.de/tl_files/gedenkstaetten/daten/stiftung/Nr_9_ April_2016.pdf).

Wolfrum, Edgar. «Erinnerungskultur und Geschichtspolitik als Forschungsfelder.» In Reformation und Bauernkrieg. Erinnerungskultur und 
Geschichtspolitik im geteilten Deutschland, hrsg. von Jan Scheunemann, 13-47. Leipzig: Evangelische Verlagsanstalt, 2010.

Wolfrum, Edgar. Geschichtspolitik in der Bundesrepublik Deutschland. Der Weg zur bundesrepublikanischen Erinnerung 1948-1990. Darmstadt: Wissenschaftliche Buchgesellschaft, 1999.

\section{Archives}

\section{Arolsen Archives. ITS2.2.0.1}

Innenministerium Schleswig-Holstein. Kriegsgräberlisten von Gudendorf.

Landesarchiv Schleswig-Holstein. Abtl. 320 Süderdithmarschen, Nr. 5854; Abtl. 454, Nr. 4.

National Archives UK. FO 371/5427, 1006/223, 1006/224, 1049/978, 1049/1288, 1081/1030/30.

Private Sammlungen: Siegfried Assmann, Helmut Hahn, Martin Gietzelt, Benno Stahn.

Staatliches Archiv der Russischen Föderation (GARF). F. 7317, op. 21 d. 4; f. 9526, op. 6, d. 255.

Zeitzeugengespräch der Verfasserin mit Benno Stahn und weiteren Mitgliedern der Initiative «Blumen für Gudendorf» vom 26.10.2018.

Zeitzeugengespräch der Verfasserin mit Hans Jakob Beeck (geb. am 06.05.1930) vom 11.09.2017.

Zeitzeugengespräch der Verfasserin mit Siegfried Assmann (geb. am 01.02.1925) vom 15.09.2018.

Zentralarchiv des Verteidigungsministeriums der Sowjetunion (CAMO)/ OBD-Memorial. Abtl. 9, Fondsnr. 58, Inventarnr. 977520, Dateinr. 2438, Erkennungsmarkennummer 124847, Stalag X B; Inventarnr. 977521, Dateinr. 1348, Erkennungsmarkennummer 209760, Stalag Iv B; Inventarnr. 977521, Dateinr. 1943, Erkennungsmarkennummer 34609, Stalag X D; Inventarnr. 977528, Dateinr. 55, Erkennungsmarkennummer 118242, Stalag X B. 